\title{
Proximate composition and amino acid profile of European eel skin: influence of body weight
}

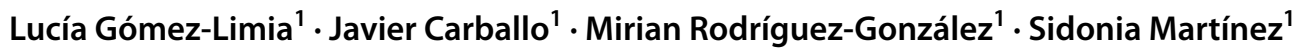

Received: 8 November 2021 / Revised: 24 January 2022 / Accepted: 29 January 2022 / Published online: 18 February 2022

(c) The Author(s) 2022

\begin{abstract}
Fish processing industries worldwide are discarding million kilograms of fish waste per year. The disposal of these wastes is an important handicap in fish processing industry. The thick eel skin is considered a waste product in the fish processing industry and in the home and is usually converted into low market-value products. The aims of this study were to evaluate the variations in the general chemical composition and amino acid content of eel skin in relation to body weight. The moisture content decreased and the lipid content increased with the weight of the eels. Eel skin had a high protein content, which did not vary significantly with eel weight. Glycine was the most abundant amino acid. The predominant essential amino acid was leucine. The smaller eels contained higher levels of threonine, valine, isoleucine, leucine, lysine, glutamic acid and tyrosine than the other groups. The larger eels contained higher levels of methionine, hydroxyproline, glycine, arginine, alanine and proline than the other groups. The protein indices showed that the skin from smaller eels was of higher nutritional quality.
\end{abstract}

\section{Graphical abstract}

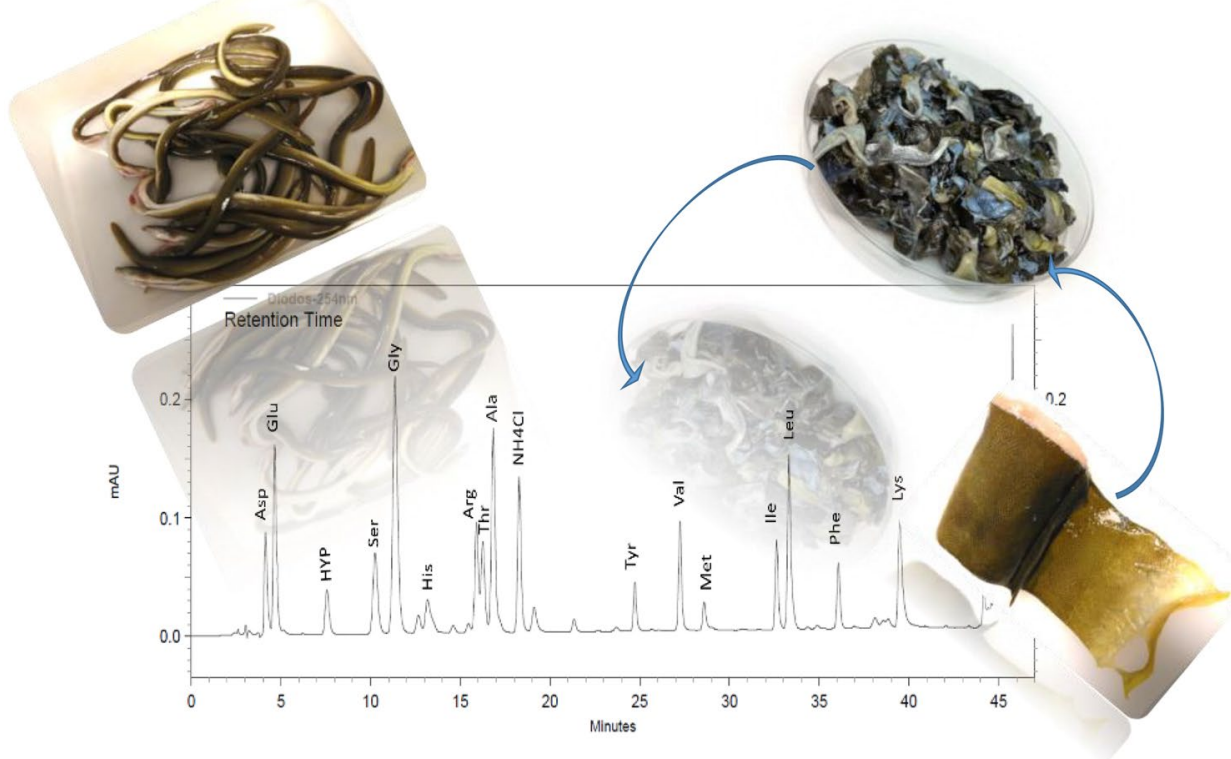

Keywords European eel $\cdot$ Skin $\cdot$ Amino acids $\cdot$ Protein quality $\cdot$ Body weight $\cdot$ Waste

Sidonia Martínez

sidonia@uvigo.es

1 Food Technology, Faculty of Science, University of Vigo,

Campus As Lagoas S/N, 32004 Ourense, Spain 


\section{Introduction}

The European eel (Anguilla anguilla L.) is a facultative catadromous fish, which undertakes a long transatlantic migration, develops in fresh water and eventually returns to the sea to spawn. The distribution area of the European eel covers all of the European coasts and part of the coasts of Africa [1]. In recent years, eels have suffered a significant decline in number. For this reason, this fish has been categorized as critically endangered by the European Union and the United Nations and has been included in the International Union for the Conservation of Nature (IUCN)'s Red List [2]. However, both fresh eels and processed products are consumed worldwide.

The main producer of eel is China, which represented $84 \%$ of world production in 2018, followed by Japan and the Republic of Korea. Japanese eel is produced in these three countries. The European Union ranks fourth and they only produce European eel. Although eel production in the EU has decreased by $19 \%$ over the last decade, in some countries such as Germany or Italy, eel production increased in the period from 2009 to 2018 [3]. A high percentage of these eels are used to make different products around the world such as smoked fish or kabayaki.

Eel processing generates large amounts of waste (scales, bone, skin, etc.). Eel skin is thick and is, therefore, considered a waste product in the fish processing industry and in the home. This type of waste is scarcely used in the fish processing industry [4]. However, use of eel skin would improve utilization of this scarce fish. Obtaining further information about the chemical composition of the eel skin and about the changes that occur throughout the biological cycle could help in the conservation and cultivation of the fish. During its life cycle, the European eel undergoes two periods of metamorphosis. The first, during its oceanic migration, involves transformation from the planktonic marine stage into the glass eel stage. The second occurs after the juvenile growth and differentiation phase in inland waters. During this second stage, eels change from yellow eels into silver eels, in a process called 'silvering' [5]. Growth involves a change in the color and thickness of the skin, accompanied by changes in skin components.

Discard and processing waste can represent between 30 and $70 \%$ of the total weight of seafood catches [6], and $\sim 30 \%$ of the waste occurs in the form of bones, skin and scales [7]. Fish waste is usually processed into low marketvalue products (animal feed, fish meal) or is dumped in the ocean, thus causing environmental problems.

Valorization of fish skin is very important to reduce fishery waste. The skin consists of three layers, with the epidermis and dermis covering the subcutaneous hypodermis. The structure, thickness and chemical composition of fish skin can vary due to the differences in species, age, weight, sex and environment and even the reproductive cycle stage $[8,9]$. These characteristics reflect how the fish are adapted to the physical, chemical and biological conditions of the aquatic environment and the natural history of the organism. Information about the chemical composition of fish skin is of interest for several reasons. One of these reasons is that when the skin is included in the final product, it is also eaten, and its characteristics can affect the nutritional value, shelf life and taste of the product [10]. Fish skin is of enormous nutritional value. In fact, fish skin is known to be a natural source of useful proteins and peptides. Protein is a major component of skin, and fish skin contains valuable amounts of proteins of high nutritional value in relation to essential amino acid composition. The protein is mainly made up of collagen, along with reticulin and elastin, which form the connective tissue matrix. The skin can be used as a substitute for bovine gelatin and for active coatings, helping to preserve food [11].

The nutritional value of proteins depends on their amino acid composition. The quality of proteins can be determined relative to the composition of a standard protein, which is accepted as the most important for the calculation of the protein quality in human nutrition. Protein quality is estimated from the amounts of limiting amino acids [12].

Considering the continued increasing demand for food, including fish, and the scarcity of eels, correct utilization of waste is of great importance. However, fish skin is seldomly used in the fish processing industry. It is well known that the proximate composition of fish is not constant, as it can vary throughout the life cycle and is affected by different factors. A significant portion of the eels remains unused or poorly used despite being in critical danger. On the other hand, further studies are required to describe the growth processes throughout the life cycle of European eels.

The purpose of this study was to evaluate how the general chemical composition, the amino acid profile and the quality of protein in the skin from the wild European eel are affected by fish size (weight), with the overall aim of exploring the potential value of eel skin and developing a zero-waste process.

\section{Materials and methods}

\section{Samples}

European eels (Anguilla anguilla) were caught in the River Ulla (Galicia, NW Spain) during the authorized fishing season (late summer and fall). They were purchased at a local market ("Plaza de Abastos, Mariscos vivos del Grove") in Ourense (Galicia, NW Spain). The eels were held in tanks connected to freshwater recirculation modules until 
slaughter. The eels were sacrificed by ice water immersion. The eels were classified according to their body weight into four different groups (15 eels per group): A 10-100 g; B $100-200 \mathrm{~g}$; C 200-400 g; and C > $200 \mathrm{~g}$. The mean total weights of the eels in groups A, B, C and D used in this study were $32.24,172.94,301.75$ and $503.55 \mathrm{~g}$, respectively. The fish were eviscerated and washed, and the skin was manually removed with the aid of a knife and cut into small squares. The skin was divided into batches and stored in the freezer at $-20{ }^{\circ} \mathrm{C}$ until use.

Before the corresponding analyses, the frozen skin eel was defrosted at $4 \pm 2{ }^{\circ} \mathrm{C}$ in a refrigerator.

\section{Proximate composition analysis}

Moisture, ash and protein content were determined as described in AOAC methods [13]. The moisture content was determined after obtaining a constant weight after drying in an oven at $105^{\circ} \mathrm{C}$. Ash content was determined after calcination of the samples in a muffle furnace at $500{ }^{\circ} \mathrm{C}$. The nitrogen $(\mathrm{N})$ content of fish skin samples was determined by the Kjeldahl method, and the value was multiplied by 6.25 to provide an estimate of the crude protein content.

The total fat was extracted from the eel skin with n-hexane solvent ( $10 \mathrm{~g}$ of minced sample with $100 \mathrm{~mL}$ of hexane). The extraction was carried out for $18 \mathrm{~h}$ in darkness, with shaking (100 rpm). The extracts were evaporated to dryness in a rotary vacuum evaporator at $60{ }^{\circ} \mathrm{C}$, and the fat content was calculated gravimetrically.

\section{Amino acid analysis}

The proteins were hydrolyzed according to the protocol described by Franco et al. [14]. The samples (100 mg) were first hydrolyzed by adding $5 \mathrm{~mL}$ of $6 \mathrm{~N} \mathrm{HCl}$ and incubating the mixture at $110^{\circ} \mathrm{C}$ for $24 \mathrm{~h}$ in a sealed glass ampoule. After hydrolysis, an aliquot of $0.625 \mathrm{~mL}$ of the sample was diluted to $25 \mathrm{~mL}$ with distilled water. The supernatant was filtered through a grease-free filter paper. The $\mathrm{pH}$ of the filtrates was adjusted to $7.1 \pm 0.2$ with a $30 \%$ potassium hydroxide solution and then cooled to $2{ }^{\circ} \mathrm{C}$ for 10 to $20 \mathrm{~min}$. The amino acids were identified and quantified by HPLC, under the conditions described by Gómez-Limia et al. [15]. The liquid chromatography equipment consisted of a Thermo Finnigan chromatograph with UV/VISIBLE detector and a Spectrasystem UV6000LP photodiode matrix. The column was a reversed phase C18 Ultrasphere 5-ODS column (diameter of $4.6 \mathrm{~mm}$ and $25 \mathrm{~cm}$ of length) (Beckman, Fullerton, USA). The temperature of the column was held at $50 \pm 1{ }^{\circ} \mathrm{C}$ with a column heater (Spectrasystem 3000). The wavelength of the detector was $254 \mathrm{~nm}$. Standards of the 17 different amino acids were supplied by Sigma Chemical Co. (St Louis, MO): L-alanine (Ala), L-arginine
(Arg), L-aspartic acid (Asp), L-glutamic acid (Glu), glycine (Gly), L-histidine (His), L-isoleucine (Ile), L-leucine (Leu), L-lysine (Lys), L-methionine (Met), L-phenylalanine (Phe), L-proline (Pro), L-serine (Ser), L-threonine (Thr), L-tyrosine (Tyr), L-valine (Val) and hydroxyproline (Hyp). As the hydrolysis conditions strongly affect the tryptophan content, this amino acid was not determined by this method. Cysteine was not evaluated in this work due to the fact that its recovery after protein hydrolysis is poor.

For derivatization, $0.2 \mathrm{~mL}$ of standard solution or hydrolyzed sample was dried in a vacuum centrifuge concentrator at $37{ }^{\circ} \mathrm{C}$. Twenty $\mu \mathrm{L}$ of the derivatizing solution (ethanol + Milli-Q water + triethylamine + phenyl isothiocyanate: PITC) was then added to each dried sample and the mixture were allowed to stand at room temperature for $20 \mathrm{~min}$. Next the resulting mixture was evaporated in a vacuum centrifuge concentrator at $37^{\circ} \mathrm{C}$. The dry residue was dissolved with $500 \mu \mathrm{L}$ of diluent (disodium acid phosphate $(675.4 \mathrm{mg}$ ) and Milli-Q water $(950 \mathrm{~mL})$. The mixture was filtered (Waters $0.45 \mu \mathrm{m}$ pore diameter filters) and transferred into a sample vial for HPLC analysis. A solution of anhydrous sodium acetate in Milli-Q water, adjusted to $\mathrm{pH} 6.6$ with glacial acetic acid, was mixed with acetonitrile (40:60) to produce eluent A. A solution of Milli-Q water and acetonitrile (40:60) was used as eluent B. All samples and standards were injected in the column at least in triplicate. Tests of repeatability and reproducibility of amino acid analysis did not reveal any significant differences in either parameter.

The results are expressed as $\mathrm{g} / 100 \mathrm{~g}$ wet sample.

\section{Evaluation of amino acid quality indices and scores}

The protein quality and nutritional values of the essential amino acids scores (EAAS) determined for essential amino acids were calculated and expressed relative to the FAO/ WHO/UNU reference protein [12], as follows:

$\operatorname{EAAS}(\%)=\frac{\text { Amount of } A A \text { in the sample }(\mathrm{mg} / \mathrm{g})}{\text { Amount of } A A \text { of pattern protein }(\mathrm{mg} / \mathrm{g})} \times 100$.

The essential amino acids index (EAAI) was determined by applying the following equation, as described by Friedman [16]:

$E A A I=100 x \sqrt[n]{\frac{a}{a e} \times \frac{b}{b e} \times \frac{c}{c e} \ldots \frac{j}{j e}}$,

where $a, b, c, \ldots, j=$ His, Thr, Val, Met, Ile, Leu, Phe + Tyr and Lys content of each sample (g/100 g protein); $a e, b e$, $c e, \ldots, j e=$ His, Thr, Val, Met, Ile, Leu, Phe + Tyr and Lys content of the protein standard (g/100 g protein) [12]; $n=$ number of amino acids analyzed. 
Fig. 1 Weight (g) of the whole eels and percentage $(\%)$ of skin in each group (mean \pm standard deviation)

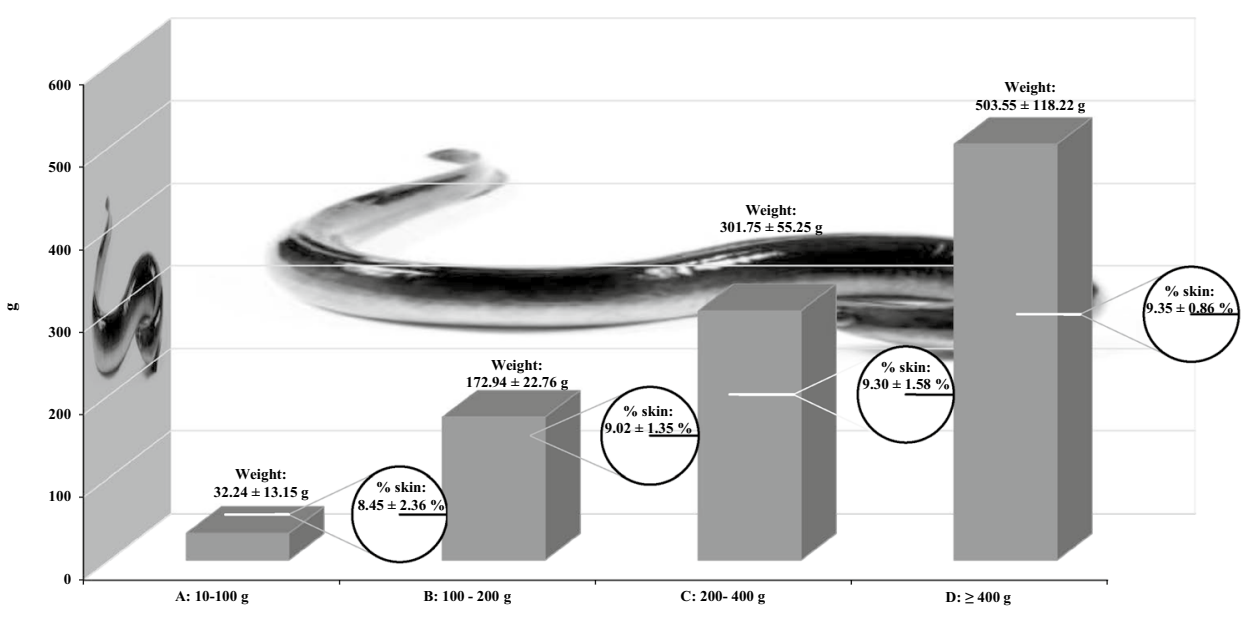

The predicted protein efficiency ratio (P-PER) was calculated using the equation proposed by Alsmeyer et al. [17], as adapted by Adeyeye [18]:

$\mathrm{P}-\mathrm{PER}=-0.468+0.454 \times$ Leu $-0.105 \times$ Tyr.

\section{Statistical analysis}

All analyses were carried out at least in triplicate. Statistical treatment of the data was carried out by analysis of variance (ANOVA). The least significant difference (LSD) test was applied with a $95 \%$ confidence interval $(P \leq 0.05)$ for comparison of the mean values, using the statistical software Statistica version 7.1 of Statsoft (C Inc. (Tulsa, OK, USA). Data are presented as means \pm standard deviation (SD).

Canonical discriminant analysis (CDA) was used to classify eels into the different groups according to weight. A stepwise selection procedure was first used to reduce the number of explanatory variables, and a canonical discrimination procedure was then used to determine the key point variables that would contribute to a discrimination function, in order to identify the relationships between these data, according to the variability in weight.

\section{Results and discussion}

\section{Sample characteristics and proximate composition of eel skin}

The average weight of the whole eels and percentage of skin in each group are shown in Fig. 1.

Eels increase in weight during development. Skin constituted between 8.45 and $9.35 \%$ of the whole eels. Although the percentage of skin increased with the size of the eels, no statistically significant differences between the groups were observed in this variable. As eel skin is often treated as waste, a high percentage of skin would signify that a large part of eel is discarded and remains unexploited.

The body composition of the fish varies during the life cycle. The chemical composition of skin can vary with age, sex, season feeding and the treatment of the skin on removal from the carcass [19]. The moisture, protein, lipid, and ash contents of the skin of European eels of different weights are shown in Table 1.

The moisture content of the skin was between $68.94 \pm 0.13$ and $63.73 \pm 2.13 \%$. The moisture content of the eel skin was lower than reported by Gómez-Limia, et al. [20] for eel muscle (74.5\%). The skin of larger eels had a lower moisture content. The moisture content of eels in groups $\mathrm{C}$ and $\mathrm{D}$ (greater weight) differed significantly from those in group A $(P<0.05)$. Muyonga et al. [8], Rosmawati et al. [9] and Mahboob [21] observed that the skin of larger fish had a lower moisture content. During growth of the fish, changes occur in the moisture content in the fish body, especially the element of moisture bound by proteins, due to biochemical activities of the body [9].

Protein is the main component of skin, after water $(20.88 \pm 2.83$ to $25.17 \pm 5.34 \%)$. The protein content increased with the weight of the eels, although the differences were not significant. This is consistent with observations made by Veeruraj et al. [22] for outer skin from eel (21.71\%). Muyonga et al. [8] also observed a protein content of $20-22 \%$ in skin of the Nile perch. Muralidharan et al. [23] reported that the skin of the leatherjacket fish (Oligoplites saurus) contained $21.65 \%$ of protein, which is consistent with our findings. Mahboob [21] did not observe any differences in protein content of South Asian carp (Catla catla) and white carp (Cirrhinus mrigala) in relation to weight.

The fat content of eel skin was quite high $(7.30 \pm 0.33$ to $10.57 \pm 1.08 \%$ ). Prior research yielded similar results for eel muscle [20]. The fat content in smaller eels (A and B) differed significantly from that in larger eels $(\mathrm{C}$ and $\mathrm{D})$. Eels 
Table 1 Proximate composition of European eel skin (\%)

\begin{tabular}{lrrrr}
\hline & A & B & C & \multicolumn{1}{c}{ D } \\
\hline Moisture & $68.94 \pm 0.13^{\mathrm{a}}$ & $68.31 \pm 3.36^{\mathrm{a}, \mathrm{b}}$ & $63.73 \pm 2.13^{\mathrm{b}}$ & $64.16 \pm 0.76^{\mathrm{b}}$ \\
Protein & $21.05 \pm 2.10^{\mathrm{a}}$ & $20.88 \pm 2.83^{\mathrm{a}}$ & $25.13 \pm 5.56^{\mathrm{a}}$ & $25.17 \pm 5.34^{\mathrm{a}}$ \\
Lipid & $7.32 \pm 0.04^{\mathrm{a}}$ & $7.30 \pm 0.33^{\mathrm{a}}$ & $10.57 \pm 1.08^{\mathrm{b}}$ & $8.24 \pm 0.67^{\mathrm{b}}$ \\
Ash & $2.58 \pm 0.30^{\mathrm{a}}$ & $2.79 \pm 0.44^{\mathrm{a}}$ & $2.30 \pm 0.14^{\mathrm{a}}$ & $3.00 \pm 0.30^{\mathrm{a}}$ \\
\hline
\end{tabular}

A: between 10 and $100 \mathrm{~g}$; B: between 100 and $200 \mathrm{~g}$; C: between 200 and $400 \mathrm{~g}$; D: more than $400 \mathrm{~g}$

${ }^{\mathrm{a}, \mathrm{b}}$ Mean values of at least three determinations \pm standard deviation with different superscripts in the same row were significantly different $(P<0.05)$ accumulate lipid during development. Luzzana et al. [24] pointed out that significant fat deposition during growth is characteristic of eels. This may be due to the need to store energy for migration. Furthermore, the importance of lipids for survival during overwintering in freshwater and for survival at sea in some species such as salmonids has been pointed out [25]. Young fish generally have higher moisture and lower lipid contents than adults. Important variations in lipid content have been reported in many studies and attributed to factors such as season, temperature, diet, age, size and sex [26]. In Spain, eel fishing season is fixed every year. Depending on the fishing season, the fat content in the eel can vary as it is conditioned by factors such as water temperature. Lipids must be removed from some products obtained from skin, such as gelatin, as they can decrease the quality of these products.

The European eel skin was low in ash content. The ash content ranged from $2.30 \pm 0.14$ to $3.00 \pm 0.30 \%$, and the differences between large and small eels were not significant. Our data are similar to those reported by Veeruraj et al. [22] for outer skin of eels $(2.12 \%)$. The ash content of fish skin can be derived from the dermis layer. It is influenced by habitat, environmental, fish species, size, age, etc. It has also been observed that a higher ash content in the skin of adult fish may be due to increased mineralization with age, thickness of the skin and biochemical composition $[8,23]$.

\section{Amino acid profile}

A total of 17 amino acids were quantified in the eel skin. The results, expressed as $\mathrm{g}$ of amino acid/100 $\mathrm{g}$ of skin, are shown in Table 2.

Glycine was the most abundant amino acid in all groups (between $3.13 \pm 0.55$ and $5.02 \pm 0.50 \mathrm{~g} / 100 \mathrm{~g}$ ). The contents increased significantly with body weight. High levels of glycine indicate the presence of collagen, as glycine is thought to be essential in collagen formation. Different studies have revealed that glycine is the most abundant amino acid in fish skin [27, 28]. Rosmawati et al. [9] observed that the glycine content was highest in medium sized fish followed by large fish and small fish.
The glutamic acid content of the eel skin was also relatively high and decreased $(1.83 \pm 0.24$ to $1.65 \pm 0.23 \mathrm{~g} / 100 \mathrm{~g})$ as the weight of the eel increased, although not significantly. This amino acid plays an important role in amino acid metabolism [29]; it is also an important source of nitrogen and contributes to the umami taste of foods.

Arginine and alanine were also detected in valuable amounts. These amino acids are non-essential, and their levels increased with increasing fish body weight. Arginine plays an important role in the production of hydroxyproline, which is used in the formation of connective tissue [9]. On the other hand, alanine plays an important role in gelatin viscosity and together with methionine is considered an indicator of protein quality [30]. Glycine, arginine and alanine induce the formation of new tissues for wound healing [29].

Proline is classified as a non-essential amino acid, but it is very important for preserving collagen structure. In addition, nutritionally, proline is involved in wound healing, antioxidant reactions and immune responses [31]. The proline contents of eel skin were high and increased with the weight of the eels.

The hydroxyproline content was higher in larger eels $(1.57 \pm 0.11 \mathrm{~g} / 100 \mathrm{~g}$ in $\mathrm{C}$ and $1.72 \pm 0.31 \mathrm{~g} / 100 \mathrm{~g}$ in D) than in smaller eels $(0.99 \pm 0.06 \mathrm{~g} / 100 \mathrm{~g}$ in $\mathrm{A}$ and $0.98 \pm 0.04 \mathrm{~g} / 100 \mathrm{~g}$ in $\mathrm{B}$ ). As this amino acid is strongly represented in collagen and elastin, it is assumed that all of the hydroxyproline content of skin is due to collagen.

The sum of hydroxyproline and proline (imino acid content) is often used to explain some properties of collagen [32]. The combined content is related to the temperature at which collagen is denaturated. The imino acid content of the eel skin $(2.61 \pm 0.23-4.78 \pm 0.58 \mathrm{~g} / 100 \mathrm{~g})$ increased with the weight of the eels. These results are consistent with the protein content of eel skin, as the higher protein concentration corresponds to a higher level of hydroxyproline. This may be due to higher collagen content in the skin of larger eels, as hydroxyproline is known to be a major constituent contributing to the stiffness of the collagen triple helix and to the intramolecular cross-links. The amounts of imino acids vary significantly among species, temperature and the eel habitat $[8,32]$. 
Table 2 Amino acid profiles (g/100 g sample), essential amino acid index $(E A A I)$ and predicted protein efficiency ratio (P-PER) of the skin of European eel

\begin{tabular}{|c|c|c|c|c|}
\hline & A & B & $\mathrm{C}$ & $\mathrm{D}$ \\
\hline \multicolumn{5}{|l|}{ Essentials (E) } \\
\hline Histidine & $0.55 \pm 0.08^{\mathrm{a}}$ & $0.55 \pm 0.08^{\mathrm{a}}$ & $0.51 \pm 0.06^{\mathrm{a}}$ & $0.51 \pm 0.07^{\mathrm{a}}$ \\
\hline Threonine & $0.78 \pm 0.06^{\mathrm{a}}$ & $0.77 \pm 0.08^{\mathrm{a}}$ & $0.56 \pm 0.08^{b}$ & $0.52 \pm 0.06^{\mathrm{b}}$ \\
\hline Valine & $0.73 \pm 0.07^{\mathrm{a}}$ & $0.74 \pm 0.06^{\mathrm{a}}$ & $0.55 \pm 0.07^{\mathrm{b}}$ & $0.60 \pm 0.06^{\mathrm{b}}$ \\
\hline Methionine & $0.25 \pm 0.03^{\mathrm{a}}$ & $0.25 \pm 0.03^{\mathrm{a}}$ & $0.28 \pm 0.05^{\mathrm{a}}$ & $0.40 \pm 0.08^{\mathrm{b}}$ \\
\hline Isoleucine & $0.62 \pm 0.07^{\mathrm{a}}$ & $0.62 \pm 0.05^{\mathrm{a}}$ & $0.41 \pm 0.06^{\mathrm{b}}$ & $0.44 \pm 0.04^{b}$ \\
\hline Leucine & $1.36 \pm 0.18^{\mathrm{a}}$ & $1.33 \pm 0.16^{\mathrm{a}}$ & $0.85 \pm 0.05^{\mathrm{b}}$ & $0.92 \pm 0.06^{\mathrm{b}}$ \\
\hline Phenylalanine & $0.75 \pm 0.10^{\mathrm{a}}$ & $0.74 \pm 0.08^{\mathrm{a}}$ & $0.64 \pm 0.04^{\mathrm{a}}$ & $0.66 \pm 0.03^{\mathrm{a}}$ \\
\hline Lysine & $0.70 \pm 0.05^{\mathrm{a}}$ & $0.68 \pm 0.08^{\mathrm{a}}$ & $0.40 \pm 0.03^{b}$ & $0.43 \pm 0.04^{b}$ \\
\hline \multicolumn{5}{|l|}{ Non-essentials (NE) } \\
\hline Hydroxyproline & $0.99 \pm 0.06^{\mathrm{a}}$ & $0.98 \pm 0.04^{\mathrm{a}}$ & $1.57 \pm 0.11^{\mathrm{b}}$ & $1.72 \pm 0.31^{\mathrm{b}}$ \\
\hline Aspartic acid & $1.09 \pm 0.06^{\mathrm{a}}$ & $1.09 \pm 0.06^{\mathrm{a}}$ & $1.02 \pm 0.19^{\mathrm{a}}$ & $1.03 \pm 0.15^{\mathrm{a}}$ \\
\hline Glutamic acid & $1.83 \pm 0.24^{\mathrm{a}}$ & $1.76 \pm 0.28^{\mathrm{a}}$ & $1.69 \pm 0.24^{\mathrm{a}}$ & $1.65 \pm 0.23^{\mathrm{a}}$ \\
\hline Serine & $0.83 \pm 0.09^{\mathrm{a}}$ & $0.82 \pm 0.10^{\mathrm{a}}$ & $0.87 \pm 0.05^{\mathrm{a}}$ & $0.89 \pm 0.14^{\mathrm{a}}$ \\
\hline Glycine & $3.13 \pm 0.55^{\mathrm{a}}$ & $3.14 \pm 0.51^{\mathrm{a}}$ & $4.10 \pm 0.49^{\mathrm{b}}$ & $5.02 \pm 0.50^{\mathrm{b}}$ \\
\hline Arginine & $1.61 \pm 0.25^{\mathrm{a}}$ & $1.73 \pm 0.34^{\mathrm{a}, \mathrm{b}}$ & $1.99 \pm 0.20^{\mathrm{b}, \mathrm{c}}$ & $2.20 \pm 0.34^{\mathrm{c}}$ \\
\hline Alanine & $1.73 \pm 0.28^{\mathrm{a}}$ & $1.75 \pm 0.31^{\mathrm{a}}$ & $1.90 \pm 0.22^{\mathrm{a}, \mathrm{b}}$ & $2.56 \pm 0.48^{\mathrm{b}}$ \\
\hline Proline & $1.59 \pm 0.45^{\mathrm{a}}$ & $1.54 \pm 0.22^{\mathrm{a}}$ & $2.17 \pm 0.22^{\mathrm{b}}$ & $2.97 \pm 0.33^{\mathrm{c}}$ \\
\hline Tyrosine & $0.43 \pm 0.07^{\mathrm{a}}$ & $0.43 \pm 0.06^{\mathrm{a}}$ & $0.31 \pm 0.03^{b}$ & $0.30 \pm 0.05^{\mathrm{b}}$ \\
\hline Imino acids & $2.70 \pm 0.34^{\mathrm{a}}$ & $2.61 \pm 0.23^{\mathrm{a}}$ & $3.69 \pm 0.29^{b}$ & $4.78 \pm 0.58^{\mathrm{c}}$ \\
\hline Hydrophobic amino acids & $10.31 \pm 0.83^{\mathrm{a}}$ & $10.23 \pm 1.02^{\mathrm{a}}$ & $10.77 \pm 0.46^{\mathrm{a}}$ & $13.41 \pm 0.94^{b}$ \\
\hline Hydrophilic amino acids & $7.10 \pm 0.49^{\mathrm{a}}$ & $7.18 \pm 0.56^{\mathrm{a}}$ & $7.48 \pm 0.47^{\mathrm{a}}$ & $8.05 \pm 0.55^{\mathrm{a}}$ \\
\hline Aromatic amino acids & $1.20 \pm 0.09^{\mathrm{a}}$ & $1.22 \pm 0.06^{\mathrm{a}}$ & $0.95 \pm 0.07^{\mathrm{b}}$ & $0.97 \pm 0.07^{\mathrm{b}}$ \\
\hline Total essentials (E) & $5.71 \pm 0.52^{\mathrm{a}}$ & $5.76 \pm 0.43^{\mathrm{a}}$ & $4.16 \pm 0.24^{b}$ & $4.49 \pm 0.25^{b}$ \\
\hline Total non-essentials (NE) & $12.68 \pm 1.44^{\mathrm{a}}$ & $13.26 \pm 1.19^{\mathrm{a}}$ & $14.87 \pm 1.05^{\mathrm{a}, \mathrm{b}}$ & $18.41 \pm 1.01^{\mathrm{b}}$ \\
\hline TOTAL & $18.29 \pm 2.16^{\mathrm{a}}$ & $18.96 \pm 1.34^{\mathrm{a}}$ & $19.44 \pm 1.13^{\mathrm{a}}$ & $21.70 \pm 2.17^{b}$ \\
\hline $\mathrm{E} / \mathrm{NE}$ ratio & $0.45 \pm 0.07^{\mathrm{a}}$ & $0.44 \pm 0.04^{\mathrm{a}}$ & $0.28 \pm 0.03^{b}$ & $0.24 \pm 0.02^{\mathrm{b}}$ \\
\hline EAAI & $110.86 \pm 4.68^{\mathrm{a}}$ & $114.09 \pm 4.03^{\mathrm{a}}$ & $83.21 \pm 7.41^{\mathrm{b}}$ & $81.50 \pm 7.39^{b}$ \\
\hline P-PER & $2.06 \pm 0.32^{\mathrm{a}}$ & $2.02 \pm 0.47^{\mathrm{a}}$ & $1.08 \pm 0.17^{\mathrm{b}}$ & $1.08 \pm 0.23^{\mathrm{b}}$ \\
\hline
\end{tabular}

A: from 10 and $100 \mathrm{~g}$; B: from 100 and $200 \mathrm{~g}$; C: from 200 and $400 \mathrm{~g}$; D: more than $400 \mathrm{~g}$. Hydrophobic amino acids: $\sum$ Proline + alanine + valine + methionine + glycine + isoleucine + leucine + phenylalanine . Hydrophilic amino acids: $\sum$ Lysine + serine + arginine + hydroxyproline + aspartic acid + glutamic acid. Aromatic amino acids: $\sum$ Tyrosine + phenylalanine

${ }^{\mathrm{a}-\mathrm{c}}$ Mean values of at least three determinations \pm standard deviation with different superscripts in the same row were significantly different $(P<0.05)$
The predominant essential amino acid in eel skin was leucine, which, together with alanine, is often present in a higher proportion in collagen. The amount of leucine decreased with the weight of the eels. These findings are consistent with those reported by Rosmawati et al. [9].

Methionine was the amino acid present at lowest concentrations in small eels $(0.25 \pm 0.03 \mathrm{~g} / 100 \mathrm{~g})$. This amino acid increased as the fish body weight increased. However, other amino acids such as threonine, valine, isoleucine, phenylalanine, lysine and tyrosine decreased as the weight of fish increased.

On the other hand, the antioxidant capacity and functional properties of protein depend on amino acid composition and hydrophobicity [33]. The hydrophobic amino acid content of eel skin
(Proline + alanine + valine + methionine + glycine + isoleucine + leucine + phenilalanine) was relatively high (between 53.95 and $61.79 \%$ of total amino acids). These amino acids can contribute to antioxidant and angiotensin-converting enzyme inhibitory activity [34]. PeñaRamos et al. [35] pointed out that hydrophobic amino acid and histidine lowered lipid oxidation considerably. Gómez-Guillén et al. [36] reported that a higher content of hydrophobic amino acid residue effectively distributes hydrophilic/hydrophobic amino acids that improve gelatinemulsifying properties.

The hydrophilic amino acids (lysine, serine, arginine, hydroxyproline, and aspartic and glutamic acids) were present in lower amounts (between 37.10 and $38.82 \%$ of total amino acids) than hydrophobic amino acids. This is 
important as the water holding capacity of some products such as gelatins and hydrolysates is affected by the amount of hydrophilic amino acids.

Aromatic amino acids (tyrosine and phenylalanine) can stabilize reactive oxygen species through direct electron transfer [37]. These amino acids, together with hydrophobic amino acids and methionine, have been reported to play an important role in antioxidative activities [38]. The contents of these amino acids in eel skin decreased as the weight of the fish increased.

The concentration of essential amino acids was higher in smaller eels than in larger eels. The sum of essential amino acids ranged between $5.71 \pm 0.52$, in the smallest eels (A), and $4.16 \pm 0.24$ in the largest eels (C). Although the sum of essential amino acids decreased during growth, the sum of non-essential amino acids increased.

Comparison of data on eels of different weights revealed significant differences $(P<0.05)$ in the $\mathrm{E} / \mathrm{NE}$ ratio. The ratio was highest in the small eels (group A: $0.45 \pm 0.07$; group B: $0.44 \pm 0.04)$.

The amino acids content in the fish skins is affected by differences factors as species, age, diet, habitat environment and especially temperature [39-41]. These factors can cause significant changes in the composition and properties of skin proteins [42]. The eels used in this study were caught in the same area and during the same time of year. Therefore, the differences observed in the content of some amino acids could be due to the changes that the collagen undergoes throughout the growth of the fish, the diet in each phase of development, or the physiological state of the eel.

Table 2 also shows the essential amino acid index (EAAI) and the predicted protein efficiency ratios (P-PER) for proteins in eel skin. EAAI and PER are considered important parameters for comparison of quality based on estimation of protein quality. The EAAI was $110.86 \pm 4.68$ and 114.09 in eels of groups A and B, showing that the sum of essential amino acids in the protein of smaller eels was higher than in the reference standard protein [12]. A similar value was reported for gilthead sea bream (Sparus aurata) skin (114.22) [43]. However, the EAAI decreased significantly as the weight of the eels increased (83.21 $\pm 7.41-81.50 \pm 7.39)$.

The predicted protein efficiency ratio (P-PER) indicates the biochemical availability of protein through measurement of animal growth. This parameter is based on the concentrations of Leu and Tyr. The standard reference for the P-PER is based on casein, a cow milk protein, which has a P-PER of 2.5 [44]. The P-PER in this study ranged between 2.06 and 2.02 in smaller eels (groups A and B) to 1.08 in heavier eels (groups $\mathrm{C}$ and $\mathrm{D}$ ). These values were lower than those obtained in a previous study in eel muscle [15]. However, the P-PER values of eel skin were higher than obtained in skin from other types of animals, such as dog, goat, pig and cane rat $(-0.20,-0.19,-0.11$ and -0.09 , respectively) [45].

Food with P-PER values below 1.5 has been reported to have low quality protein, those with P-PER between 1.5 and 2.0 have protein of intermediate quality, and those with P-PER higher than 2.0 have high quality protein $[16,46]$. Thus, the skin of smaller eels has higher quality protein than the skin of larger eels.

The amino acid scores determine the effectiveness with which absorbed dietary nitrogen, by comparing the levels of essential amino acids between samples and standard proteins. Protein quality depends on an appropriate essential amino acid score (EAAS) in the protein source considered. The mean EAAS values proposed by [12] for humans (catchup growth) are shown in Table 3. Analysis of the EAAS enables the order of the restrictive amino acids to be determined. Smaller eel yielded the best results. Histidine, threonine and aromatic amino acids (phenylalanine + tyrosine) were the amino acids associated with the highest EAAS values. According to the results reported by other authors, histidine is one of the amino acids with the highest EAAS
Table 3 Essential amino acid scores (EAAS) of European eel skin based on provisional amino acid scores

\begin{tabular}{lccccc}
\hline & A & B & C & D & $\begin{array}{l}\text { Protein } \\
\text { standard* }\end{array}$ \\
\hline Histidine & $177.53 \pm 33.41^{\mathrm{a}}$ & $172.24 \pm 38.20^{\mathrm{a}}$ & $171.06 \pm 25.87^{\mathrm{a}}$ & $152.15 \pm 15.24^{\mathrm{a}}$ & 1.50 \\
Threonine & $162.92 \pm 19.84^{\mathrm{a}}$ & $144.97 \pm 29.43^{\mathrm{a}}$ & $119.97 \pm 19.66^{\mathrm{b}}$ & $111.86 \pm 19.50^{\mathrm{b}}$ & 2.30 \\
Valine & $87.34 \pm 9.43^{\mathrm{a}}$ & $81.32 \pm 15.32^{\mathrm{a}, \mathrm{b}}$ & $74.612 \pm 5.87^{\mathrm{b}, \mathrm{c}}$ & $68.49 \pm 11.16^{\mathrm{c}}$ & 3.90 \\
Methionine & $79.86 \pm 8.75^{\mathrm{a}}$ & $78.97 \pm 13.81^{\mathrm{a}}$ & $85.06 \pm 17.56^{\mathrm{a}}$ & $88.23 \pm 10.67^{\mathrm{a}}$ & 1.60 \\
Isoleucine & $97.26 \pm 9.34^{\mathrm{a}}$ & $96.26 \pm 15.80^{\mathrm{a}}$ & $70.95 \pm 10.72^{\mathrm{b}}$ & $67.61 \pm 10.70^{\mathrm{b}}$ & 3.00 \\
Leucine & $105.58 \pm 12.74^{\mathrm{a}}$ & $100.29 \pm 17.67^{\mathrm{a}}$ & $73.75 \pm 7.70^{\mathrm{b}}$ & $70.04 \pm 6.28^{\mathrm{b}}$ & 5.90 \\
Phe+Tyr & $154.85 \pm 12.09^{\mathrm{a}}$ & $167.04 \pm 23.42$ & $128.03 \pm 12.52^{\mathrm{b}}$ & $121.18 \pm 15.25^{\mathrm{b}}$ & 3.80 \\
Lysine & $76.20 \pm 7.54^{\mathrm{a}}$ & $75.25 \pm 10.52^{\mathrm{a}}$ & $47.83 \pm 3.54^{\mathrm{b}}$ & $48.15 \pm 5.72^{\mathrm{b}}$ & 4.50 \\
\hline
\end{tabular}

A: from 10 and $100 \mathrm{~g}$; B: from 100 and $200 \mathrm{~g}$; C: from 200 and $400 \mathrm{~g}$; D: more than $400 \mathrm{~g}$ *FAO/WHO/UNU (2007) (g/100 g protein). Indispensable amino acid requirements (catch-up growth) ${ }^{a-c}$ Means in the same row with different letters differ significantly $(P<0.05)$. Phe + Tyr: phenylalanine + tyrosine 
values, while methionine is a limiting amino acid in fish by-products [43].

Methionine, valine, isoleucine and lysine were present in small amounts in all of the fish. The EAAS of these amino acids, except methionine, decreased with increasing weight of fish. Leucine also was a limiting amino acid in larger fish.

Multivariate statistical techniques were used with the aim of discriminating between skins of eels of different size. The data on all amino acids studied were included in

Table 4 Results of canonical discriminant analysis: standardized canonical coefficients and discriminant functions (F1 and F2)

\begin{tabular}{lll}
\hline & $F 1$ & $F 2$ \\
\hline Threonine & 0.403 & -0.250 \\
Valine & -0.694 & -0.297 \\
Isoleucine & 0.229 & -0.217 \\
Lysine & 0.466 & 0.428 \\
Total amino acids & 9.865 & 12.89 \\
No essential amino acids & -9.505 & -11.091 \\
Essential amino acids & -1.988 & -2.484 \\
Hydrophobic amino acids & -0.258 & -0.389 \\
Aromatic amino acids & -0.750 & -1.1091 \\
Statistics & & \\
Canonical R & 0.95 & 0.74 \\
Eigenvalue & 9.95 & 1.19 \\
Cumulative proportion & 0.89 & 0.99 \\
\hline
\end{tabular}

the factorial analysis to identify the variables that contributed most to the classification.

Nine selected significant parameters, i.e., threonine, valine, isoleucine, lysine, total amino acids, total nonessential amino acids, total essential amino acids, hydrophobic amino acids and aromatic amino acids (Table 4), were subjected to linear discriminant analysis.

Two discriminating functions were statistically significant $(P<0.05)$. The loading plot shows the involvement of different amino acids contributing to the groupings shown in Fig. 2. The skin of the two groups of larger eels (C and D) was clearly distinguished. However, separation between samples of groups A and B was not satisfactory, possibly due to the small differences in amino acid composition between these groups.

The most significant function $(P<0.05)$ was $\mathrm{F} 1$. The first principal component (F1) explained $88.83 \%$ and the second component (F2) explained $10.65 \%$ of the total variation.

\section{Conclusions}

Utilization of eel skin would valorize this waste product and improve use of this scarce fish species, while also reducing environmental pollution. The chemical composition of eel skin is related to the body size of the fish. The moisture content was higher in skin from smaller eels; however, the percentage of lipid was higher in skin from larger
Fig. 2 Scatter plot produced from linear discriminant analysis (LDA). A: from 10 and $100 \mathrm{~g}$; B: from 100 and $200 \mathrm{~g}$; $\mathrm{C}$ : from 200 and $400 \mathrm{~g}$; D: more than $400 \mathrm{~g}$

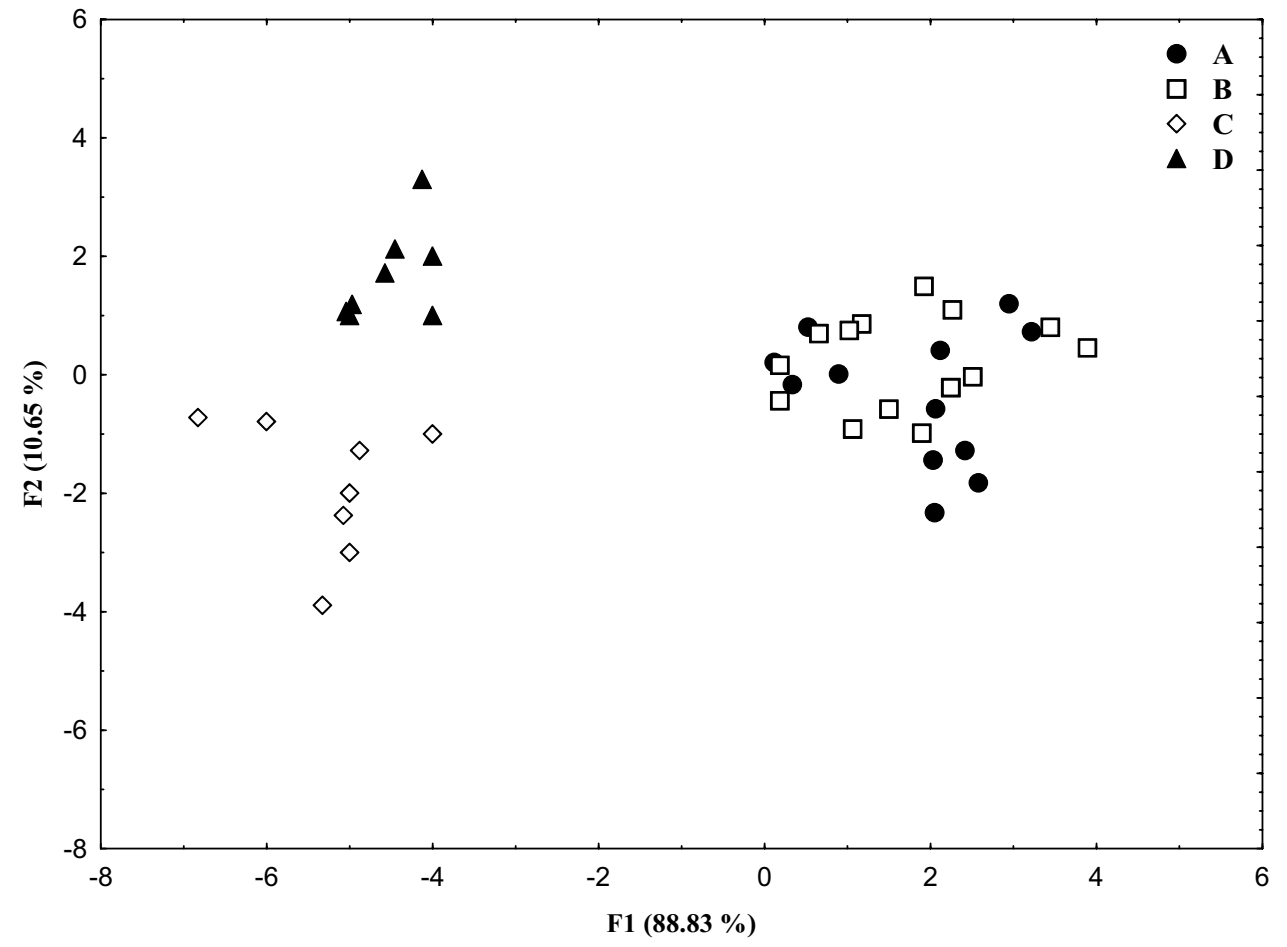


eels. Protein and ash contents did not undergo significant changes according to fish size. The high glycine, proline and hydroxyproline contents indicated that eel skin might be a good source of collagen. The results show that differences in eel body weight are associated with significant differences in hydroxyproline content, indicating that the amount of collagen increases with eel weight. Eel skin may also be a good source of protein and some amino acids, and it could be used as an ingredient in different foods. In any case, variations in the composition of eel skin due to the weight of the fish should be taken into account. These changes may also be related to the biology and life cycle of the fish.

Acknowledgements Thanks to the Xunta de Galicia for its financial support under the Consolidation and restructuring program of competitive research units: Strategic Research Partnerships (2009/060) (CITACA Strategic Partnership ED431E 2018/07). The first author acknowledges financial support from the University of Vigo through a pre-doctoral fellowship.

Funding Open Access funding provided thanks to the CRUE-CSIC agreement with Springer Nature. Funding for open access charge: Universidade de Vigo/CISUG.

\section{Declarations}

Conflict of interest The authors have no relevant financial or non-financial interests to disclose.

Compliance with ethics requirements This article does not contain any studies with human subjects.

Open Access This article is licensed under a Creative Commons Attribution 4.0 International License, which permits use, sharing, adaptation, distribution and reproduction in any medium or format, as long as you give appropriate credit to the original author(s) and the source, provide a link to the Creative Commons licence, and indicate if changes were made. The images or other third party material in this article are included in the article's Creative Commons licence, unless indicated otherwise in a credit line to the material. If material is not included in the article's Creative Commons licence and your intended use is not permitted by statutory regulation or exceeds the permitted use, you will need to obtain permission directly from the copyright holder. To view a copy of this licence, visit http://creativecommons.org/licenses/by/4.0/.

\section{References}

1. FAO/WHO/UNU (2017) Food and agriculture organization of the United Nations/World Health Organization. Aquatic species distribution map viewer. http://www.fao.org/figis/geoserver/facts heets/species.html. Accessed 14 Jan 2021

2. Pike C, Crook V, Gollock M (2020) Anguilla anguilla. The IUCN red list of threatened species 2020: e.T60344A152845178. https:// doi.org/10.2305/IUCN.UK.2020-2.RLTS.T60344A152845178. Accessed 22 Jan 2021

3. EUMOFA (European Market Observatory for Fisheries and Aquaculture Products) (2021). Smoked eel in the EU. Price structure in the supply chain focus on the Netherlands, Germany and Denmark. https://doi.org/10.2771/2362

4. Sila A, Martínez-Álvarez O, Krichen F, Gómez-Guillén MC, Bougatef A (2017) Gelatin prepared from European eel (Anguilla anguilla) skin: physicochemical, textural, viscoelastic and surface properties. Colloids Surf A Physicochem Eng Asp 529:643-650. https://doi.org/10.1016/j.colsurfa.2017.06.032

5. van Ginneken VJT, De Vries E, Verheij E (2018). The lipid composition and biochemistry of the migrating European eel (Anguilla anguilla L.): A LCMS-study following a lipidomics based systems biology approach. Adv Biochem Engin Biotechnol. https://doi. org/10.29011/2574-7258.

6. Caruso G, Floris R, Serangeli C, Di Paola L (2020) Fishery wastes as a yet undiscovered treasure from the sea: biomolecules sources, extraction methods and valorization. Mar Drugs 18:622. https:// doi.org/10.3390/md18120622

7. Blanco M, Vázquez JA, Pérez-Martín RI, Sotelo CG (2017) Hydrolysates of fish skin collagen: an opportunity for valorizing fish industry byproducts. Mar Drugs 15:131. https://doi.org/10. 3390/md15050131

8. Muyonga JH, Cole CGB, Duodu KG (2004) Extraction and physico-chemical characterization of Nile perch (Lates niloticus) skin and bone gelatin. Food Hydrocoll 18:581-592. https://doi.org/10. 1016/j.foodhyd.2003.08.009

9. Ms R, Abustam E, Tawali A, Said M, Sari DK (2018) Effect of body weight on the chemical composition and collagen content of snakehead fish Channa striata skin. Fish Sci 84:1081-1089. https://doi.org/10.1007/s12562-018-1248-8

10. Belitz HD, Grosch W, Schieberle P (2009) Fish, whales, crustaceans, mollusks. Food Chem 13:617-639. https://doi.org/10.1007/ 978-3-540-69934-7_14

11. Mirzapour-Kouhdasht A, Moosavi-Nasab M (2020) Shelf-life extension of whole shrimp using an active coating containing fish skin gelatin hydrolysates produced by a natural protease. Food Sci Nutr 8:214-223. https://doi.org/10.1002/fsn3.1293

12. FAO/WHO/UNU (2017) Food and agriculture organization of the United Nations/World Health Organization. Protein quality assessment in follow-up formula for young children and ready to use therapeutic foods: Report of an FAO Expert Consultation Rome, Italy. http://www.fao.org/3/CA2487EN/ca2487en.pdf. Accessed 14 Apr 2021

13. AOAC International (2006) Official methods of analysis of AOAC International. Md. AOAC International, Gaithersburg

14. Franco D, González L, Bispo E, Rodríguez P, Garabal JI, Moreno $\mathrm{T}$ (2010) Study of hydrolyzed protein composition, free amino acid, and taurine content in different muscles of Galician blonde beef. J Muscle Foods 21:769-784. https://doi.org/10.1111/j.17454573.2010.00218.x

15. Gómez-Limia L, Franco I, Martínez-Suárez S (2021) Effects of processing step, filling medium and storage on amino acid profiles and protein quality in canned European eels. J Food Comp Anal 96:103710. https://doi.org/10.1016/j.jfca.2020.103710

16. Friedman M (1996) Nutritional value of proteins from different food sources. A review. J Agric Food Chem 44:6-29. https://doi. org/10.1021/jf9400167

17. Alsmeyer RH, Cunningham AE, Happich ML (1974) Equations predict PER from amino acid analysis. Food Techn 28:34-38

18. Adeyeye EI (2009) Amino acid composition of three species of Nigerian fish: Clarias anguillaris, Oreochromis niloticus and Cynoglossus senegalensis. Food Chem 113:43-46. https://doi. org/10.1016/j.foodchem.2008.07.007

19. Silva TH, Moreira-Silva J, Marques AL, Domingues A, Bayon Y, Reis RL (2014) Marine origin collagens and its potential applications. Mar Drugs 12:5881-5901. https://doi.org/10.3390/md121 25881 
20. Gómez-Limia L, Cobas N, Franco I, Martínez S (2020) Fatty acid profiles and lipid quality indices in canned European eels: effects of processing steps, filling medium and storage. Food Res Int 136:109601. https://doi.org/10.1016/j.foodres.2020.109601

21. Mahboob S (2015) Isolation and characterization of collagen from fish waste material-skin, scales and fins of Catla catla and Cirrhinus mrigala. J Food Sci Technol Mys 52:4296-4305. https:// doi.org/10.1007/s13197-014-1520-6

22. Veeruraj A, Muthuvel A, Thangavel B (2013) Isolation and characterization of thermostable collagen from the marine eel-fish (Evenchelys macrura). Process Biochem 48:1592-1602. https:// doi.org/10.1016/j.procbio.2013.07.011

23. Muralidharan N, Shakila JR, Sukumar D, Jeyasekaran G (2013) Skin, bone and muscle collagen extraction from the trash fish, leather jacket (Odonus niger) and their characterization. J Food Sci Technol 50:1106-1113. https://doi.org/10.1007/ s13197-011-0440-y

24. Luzzana UM, Scolari B, Campo Dall'Orto F, Caprino G, Turchini E, Orban F, Sinesio F, Valfré F (2003) Growth and product quality of European eel (Anguilla anguilla) as affected by dietary protein and lipid sources. J Appl Ichthyol 19:74-78. https://doi.org/10. 1046/j.1439-0426.2003.00441.x

25. Dempson IB, Schwarz CJ, Shears M, Furey G (2004) Comparative proximate body composition of Atlantic salmon with emphasis on parr from fluvial and lacustrine habitats. Fish Biol 6:1257-1271. https://doi.org/10.1111/j.1095-8649.2004.00389.x

26. Özogul Y, Özyurt G, Özogul F, Kuley E, Polat A (2005) Freshness assessment of European eel (Anguilla anguilla) by sensory, chemical and microbiological methods. Food Chem 92:745-751. https://doi.org/10.1016/j.foodchem.2004.08.035

27. Bechtel PJ, Bland JM, Bett-Garber KL, Grimm CC, Brashear SS, Lloyd SW, Watson MA, Lea JM (2017) Chemical and nutritional properties of channel and hybrid catfish byproducts. Food Sci Nutr 5:981-988. https://doi.org/10.1002/fsn3.483

28. Munekata PES, Pateiro M, Domínguez R, Zhou J, Barba FJ, Lorenzo JM (2020) Nutritional characterization of sea bass processing by-products. Biomolecules 10:232. https://doi.org/10.3390/ biom 10020232

29. Mohanty B, Mahanty A, Ganguly S, Sankar TV, Chakraborty K, Rangasamy A, Paul B, Sarma D, Mathew S, Asha KK (2014) Amino acid compositions of 27 food fishes and their importance in clinical nutrition. J Amino Acids 2014:1-7. https://doi.org/10. $1155 / 2014 / 269797$

30. Giménez B, Turney J, Lizarbe MA, Montero P, Gómez-Guillẻn MC (2005) Use of lactic acid for extraction of fish skin gelatin. Food Hydrocoll 19:941-950. https://doi.org/10.1016/j.foodhyd. 2004.09.011

31. Wu G, Bazer FW, Burghardt RC, Johnson GA, Kim SW, Knabe DA, Li P, Li X, McKnight JR, Satterfield MC, Spencer TE (2011) Proline and hydroxyproline metabolism: Implication for animal and human nutrition. Amino Acids 4(1053-1063):2011. https:// doi.org/10.1007/s00726-010-0715-z

32. Jongjareonrak A, Rawdkuen S, Chaijan M, Benjakul S, Osako K, Tanaka M (2010) Chemical compositions and characterization of skin gelatin from farmed giant catfish (Pangasianodon gigas). LWT 43:161-165. https://doi.org/10.1016/j.lwt.2009.06.012

33. Chalamaiah M, Hemalatha R, Jyothirmayi R (2012) Fish protein hydrolysates: proximate composition, amino acid composition, antioxidant activities and applications: a review. Food Chem 135:3020-3038. https://doi.org/10.1016/j.foodchem.2012.06.100
34. Prihanto AA, Nurdiani R, Bagus AD (2019) Production and characteristics of fish protein hydrolysate from parrotfish (Chlorurus sordidus) head. PeerJ 7:e8297. https://doi.org/10.7717/peerj.8297

35. Peña-Ramos EA, Xiong YL, Arteaga GE (2004) Fractionation and characterisation for antioxidant activity of hydrolysed whey protein. J Sci Food Agric 84:1908-1918. https://doi.org/10.1002/ jsfa. 1886

36. Gómez-Guillén MC, Pérez-Mateos M, Gómez-Estaca J, LópezCaballero E, Giménez B, Montero P (2009) Fish gelatin: renewable material for developing active biodegradable film. Trends Food Sci Technol 20:3-16. https://doi.org/10.1016/j.tifs.2008.10. 002

37. Qian ZJ, Jung WK, Kim SK (2008) Free radical scavenging activity of a novel antioxidative peptide purified from hydrolysate of bullfrog skin, Rana catesbeiana Shaw. Bioresour Technol 99:1690-1698. https://doi.org/10.1016/j.biortech.2007.04.005

38. Rajapakse N, Mendis E, Byun HG, Kim SK (2005) Purification and in vitro antioxidative effects of giant squid muscle peptides on free radical-mediated oxidative systems. J Nutr Biochem 16:562569. https://doi.org/10.1016/j.jnutbio.2005.02.005

39. Koli JM, Sagar BV, Kamble RS, Sharangdhar ST (2014) Functional properties of gelatin extracted from four different types of fishes: a comparative study. Indian J Fund Appl Sci 4:322-327

40. Kittiphattanabawon P, Benjakul S, Visessanguan W, Shahidi F (2010) Isolation and characterization of collagen from the cartilages of brownbanded bamboo shark (Chiloscyllium punctatum) and blacktip shark (Carcharhinus limbatus). Food Sci Technol 43:792-800. https://doi.org/10.1016/j.lwt.2010.01.006

41. Huang Y, Shiau C, Chen H, Huang BC (2011) Isolation and characterization of acid and pepsin-solubilized collagens from the skin of balloon fish (Diodon holocanthus). Food Hydrocoll 25(1):507-1513. https://doi.org/10.1016/j.foodhyd.2011.02.011

42. Nurilmala M, Suryamarevita H, Husein Hizbullah H, Jacoeb AM, Ochiai Y (2021) Fish skin as a biomaterial for halal collagen and gelatin. Saudi J Biol Sci. https://doi.org/10.1016/j.sjbs.2021.09. 056 (In press)

43. Pateiro M, Munekata PES, Domínguez R, Wang M, Barba FJ, Bermúdez R, Lorenzo JM (2020) Nutritional profiling and the value of processing by-products from Gilthead Sea bream (Sparus aurata). Mar Drugs 18:101. https://doi.org/10.3390/md18020101

44. FAO/WHO/UNU (1985). Food and Agriculture Organization of the United Nations/World Health Organization. Energy and Protein Requirements, WHO Technical Report Series No. 275, Geneva

45. Ajayi OB, Akomolafe SF (2016). A comparative study on nutritional composition, mineral content and amino acid profile of the skin of four different animals. J Food Sci Nutr 2: 12. https://doi. org/10.24966/FSN-1076/100012.

46. Oluwaniyi OO, Dosumu OO, Awolola GV (2010) Effect of local processing methods (boiling, frying and roasting) on the amino acid composition of four marine fishes commonly consumed in Nigeria. Food Chem 123:1000-1006. https://doi.org/10.1016/j. foodchem.2010.05.051

Publisher's Note Springer Nature remains neutral with regard to jurisdictional claims in published maps and institutional affiliations. 